\title{
The Two-Face of Anies Baswedan: The Inconsistency with Regards to Jakarta Reclamation
}

\author{
Jean Antunes Rudolf Zico Ma'u \\ jeanmau1510@gmail.com \\ Graduate Program in English Language Studies, Universitas Sanata Dharma, INDONESIA
}

\begin{abstract}
Homo homini lupus and the end justifies the means are two general adagios that have been applied in the political contestation. The main idea behind the two adagios is that one should benefit any means necessary at all cost in order to execute the vested political agenda. Such practice is almost found in any domain of political practice, especially in the general election for governor. One of the good examples that describes the case best is the governor election of DKI-1. During this election, one of the candidates, namely Anies Baswedan, has successfully manipulated the environmental issues, namely Jakarta Reclamation, into one of his political weapons by promising that he shall cease Jakarta Reclamation if he has been officially elected as the Governor of Jakarta Special Capitol. Indeed, he has won the election and thus he has kept his commitment by sealing the 932 buildings from Island D. However, several moments later he issued the building permit for a number of buildings in one of the reclamation islands and ever since then people, especially his supporters, have started questioning his commitment toward the cessation of Jakarta Reclamation. Departing from the case, the researcher is encouraged to conduct a study that might disclose the true characteristics of a political figure. Within the conduct of the study, the researcher took a number of statements from the online news portals that have been considered trustworthy and reputable in portraying certain events especially the political ones and at the same time analysed these statements by applying the Fairclough analysis and four questions of critical paradigm. The results of the study show that: (a) Anies Baswedan has not fully kept his commitment toward the cessation of Jakarta Reclamation; and (b) the four questions of critical paradigm might be implemented for criticizing a political figure with several modifications.
\end{abstract}

Keywords: Fairclough analysis, critical paradigm, Jakarta reclamation

\section{Introduction}

Homo homini lupus is already a widely acceptable adagio in any domain of social practice and that also includes the domain of politics. Similarly, another adagio coined by Niccolò Machiavelli, the end justifies the means, is also widely acceptable in the domain of social media. Departing from the two adagios, it might be described that people, especially those who have or at least who display the thirst of power, will do whatever it takes to grant their desire even if it is at the expense of others. With regard to the statement, there have been many cases that serve as good model for illustrating how the race for power might be very gruesome.

One of the cases that has described best the above explanation might be traced to the Governor Election in Jakarta or known as Pilkada DKI Jakarta. The election took place in 2017 with three pairs of candidates in the first round and two candidates in the second round. These candidates were Anies Baswedan-Sandiaga Uno, Basuki Tjahaya Purnama-Djarot Saiful Hidayat, and Agus Harimurti Yudhoyono-Sylviana Murni. The 
election had to be conducted in two rounds because in the first round none of the candidates had met the requirement of unanimous victory. Then, the candidates who opened their way into the second round of election were Anies Baswedan-Sandiaga Uno and Basuki Tjahaya Purnama-Djarot Saiful Hidayat and this was where the fierce competition for power started.

As having been implied in the opening paragraph of this section, people tend to do whatever it takes to deliver their wish especially when it comes to power. As a result, many efforts of black campaign, altogether with hoaxes, overran the media without any clear trace on who had been running these efforts. One of the issues that had been benefitted within this situation was the Jakarta Reclamation. In one of his campaigns, Anies Baswedan, one of the candidate pairs, said that he would stop the Jakarta Reclamation if he had won the election. At the end of the election round, it turned out that Anies Baswedan-Sandiaga Uno had won the election by benefitting the issues around Jakarta, including the Jakarta Reclamation.

Two years have passed but it seems that the case of Jakarta Reclamation is far from being solved or even stopped. The recent development from the case of Jakarta Reclamation is that without having been noticed the Provincial Government of the Province of Jakarta Special Capitol has issued the Building Permit (IMB, Izin Mendirikan Bangunan) to around 932 buildings in the reclamation island. Looking at this situation, many people who used to support Anies Baswedan, start to question his commitment to stop the Jakarta Reclamation. On the other hand, the party that supports him, namely Partai Keadilan Sejahtera (Prosperous Justice Party (Hanzel, 2011)), has stated that Anies Baswedan has fulfilled his promise with regards to stop the reclamation. Anies himself has admitted that he has kept his promise to stop Jakarta Reclamation.

The controversy over the Jakarta Reclamation has intrigued the researcher to conduct a study to see how Anies Baswedan has been framed in the news items with regard to his consistency in keeping his promise to stop the Jakarta Reclamation. The importance of conducting the study is that through the framing people might learn and eventually define whether a political figure will be worth to elect or not so that in the future they will not make a political mistake that might bring about a fatal consequence. Then, in order to lead the progress in the study, the researcher would like to propose two problem statements. The first problem statement is related to how Anies Baswedan has shown his commitment to the media with regards to his commitment to stop the Jakarta Reclamation. Through the first problem statement, the researcher is trying to identify how Anies Baswedan has shown his commitment to the media in relation to his commitment to stop the Jakarta Reclamation. Next, the second problem statement is related to how people might be critical toward a political figure by observing the media frame. Hopefully, the discussions on the problem formulation will be able to provide better information on not only the framing of a political figure but also the ways to ensure the worth-selected political figure so that the results of the political contestation might not bring about fatal impact in the future.

Reclamation, or land reclamation, refers to "gain of land from the sea, the wetland or the other water bodies, the restoration of land use or land productivity that has been degraded by either the human activity or the natural phenomena" (OECD, 2001). Similarly, according to the Ministerial Regulation Number 125 of 2018 it is defined that reclamation refers to "heap work in the water area or in the coastal area that alters the coastline and/or the contour of the water depth". From both definitions, it might be concluded that reclamation is the work of expanding the coastal line by gaining land from the sea in order to open a new area that might be benefitted for multiple purposes such as trade, business, settlement and alike.

The main objective of reclamation is to turn a degraded wet area or an ill-benefitted piece of land into a new area that will be more useful and productive and the new are thus might be benefitted for certain purposes such as settlement, industrial area, business and 
trades, harbour and alike (Administrator, 2016). Departing from the objective, the benefit of conducting the reclamation is that the piece of land that might be lost due to the abrasion from the sea might be returned and that new piece of land might be opened in front of the coastline so that there will some sort of "fortress" that protects the coastal line.

Despite the benefits, the conduct of reclamation has both the positive and the negative impacts (Administrator, 2016). The positive impact is that the opening of the new area will improve the social and economic activities since there will be the construction of new settlement that will absorb labours and open small-scale business such as shops and food stalls; on the other hand, the negative impact is that the potential occurrence of flood might increase, the settlement of the fishermen might be displaced and even the environment might be deteriorated. Therefore, the conduct of the reclamation should undergo thorough planning and environmental impact analysis in order to minimize the negative impact and increase the positive impact.

The model of Fairclough analysis strives to identify and link the micro text and the macro context in the society (Eriyanto, 2001, p. 285; Fairclough, 1995). According to the model, a researcher is urged to see language as the practice of power. Therefore, the consequence is that the analysis should be based on how the language is shaped and formed by certain social contexts and social relations. Then, the model of Fairclough analysis consists of three dimensions, namely text, discourse practice, and sociocultural practice (Eriyanto, 2001, p. 286). The text should be analysed linguistically by paying attention to the vocabulary, the semantic and the grammar altogether with coherence and cohesiveness that shape the understanding toward the text. These elements are involved in the analysis in order to identify three problems namely: a) ideational, which refers to certain representation that is intended to be displayed in the text; b) relation, which refers to the analysis of the construction between the reporter and the reader; and c) identify, which refers to certain construction from the identity of both the reporter and the reader.

Departing from the text analysis, the researcher should move into the discourse practice analysis. In the discourse practice analysis, the researcher should focus the attention to how text is produced and consumed since the text is formed by means of a discourse practice. In other words, it is the discourse practice that defines how the text is shaped. Then, the relationship between the text analysis and the discourse practice analysis will lead to the sociocultural practice analysis or the third dimension within the model of Fairclough analysis. In conducting the sociocultural practice analysis, the main focus of the researcher should be on the assumption that the social context outside the media has a certain influence on the discourse that appears in the media. Therefore, newsroom might not be considered as an empty vessel but, instead, newsroom might be highly defined by the external factors. Through the intricate relationship, people will understand how the certain cases that have been portrayed might be represented within the media.

Critical paradigm is an important aspect that should be upheld in the present day especially in dealing with the news items related to terrorism. Critical paradigm was first developed in the school of Frankfurt during the Hitler era (Eriyanto, 2001, p. 23). In the era, media were not neutral they were filled with prejudice, rhetoric, and propaganda. At the same time, the German government under Hitler's leadership had benefitted the media as part of their control over the public especially in the efforts to maintain the spirit of warfare. As a result, media were controlled by the dominant party. Due to the situation, the school of Frankfurt started to contemplate the presence of different powers within the society that might control the communication process. The contemplation thus resulted into the four matters that should always be considered whenever an individual received information: a) who controlled the media; b) why he or she controlled the media; c) what benefits that might be achieved through the gain of control; and d) which groups that had not been 
dominant and that had become the object of control (Eriyanto, 2001, pp. 23-24). Apparently, the four matters are still relevant to be considered in the present-day context since the critical paradigm believes that media serves as an area in which the dominant group might control and might even marginalize the non-dominant group through the possession and the control over the media.

In brief, the birth of critical paradigm has given birth to the two views on the use of media in the social practice known as the pluralist view and the critical view. The pluralist view believes that media is an autonomous entity and therefore the news that the media report describe the reality. On the other hand, the critical view believes that media in overall are influenced by the social structure and the social strength within the society. The importance of being critical in viewing the media, specifically in relation to the news items, thus has been automatically asserted. In other words, the use of critical paradigm becomes very important since, as having been implied from the previous paragraph, media are actually amidst multiple complex and various interests, conflicts, and facts. The content of the media, specifically in the news items, are not automatically present through the mechanism of push and pull between the strong internal and external interest. Instead, what the media present might not be the actual reality but the formulation of redactional work that represents the reality through different perspective (Mubarok \& Wulandari, 2018). Through such formulation, the news items thus present a new reality that has been added, reduced, revised, omitted and even distorted from the actual reality. As a result, the content of media, specifically the news items themselves, become full of interest. Therefore, once again it is very important to implement the critical paradigm in viewing the news items so that people will have more balanced opinion on the given issues.

\section{Methodology}

In conducting the study, the researcher will implement the qualitative approach. The goal of implementing qualitative approach within a study is to gain deeper understanding toward the experience of individuals or a group of individuals (Wahyuni, 2015, p. 1). Then, a qualitative research has five characteristics. First, a qualitative research is descriptive. The data that have been collected are in the form of words or pictures and the written results of the research contain quotations from the data to illustrate and substantiate the presentation. The data might include interview, transcripts, field notes, photographs, videotapes, personal documents, memos, and other official records. Specific to the context of the study, the official records that will be selected for the conduct of the text analysis are the news that has been posted by the online news portal.

Since the study will focus on how Anies Baswedan shows his commitment to stop Jakarta Reclamation and how people might be critical toward a political figure during the campaign, several articles are collected randomly from the online news portal that has been considered trustworthy and reputable in portraying certain events especially the political ones namely: (a) Warta Ekonomi; (b) Detikcom; (c) CNN Indonesia; (d) Tirto.id; (e) Sindonews; (f) Suara.com; (g) VOA Indonesia; (h) IDN Times; and (i) Berita Satu. The selection criteria are as follows: a) the articles should display commitment of Anies Baswedan to stop Jakarta Reclamation; b) the articles should discuss the issues around Jakarta Reclamation; and c) the articles should display the response of Anies Baswedan to the issuance of building permits in the reclamation area. After all of the articles have been collected, these articles will be analysed by means of Fairclough analysis. The analysis will focus only on the text analysis. The term text analysis in this regard refers to the process of describing and interpreting the given documents to provide thorough illustration on the events that have been disclosed. Under the same spirit, the text analysis has been selected because the researcher would like to disclose the commitment of Anies Baswedan to stop Jakarta Reclamation from his statements in the media. 
Departing from the discussion on the commitment of Anies Baswedan to stop Jakarta Reclamation, the researcher will progress to the discussions on how people might be critical toward a public figure during the campaign. The discussion will be based on the results of the discussion for the first problem formulation. In dealing with this kind of criticism, the researcher will implement the theory of critical paradigm in order to encourage people to be critical toward a political figure during the campaign. As having been explained, there are four stages in conducting the critical paradigm namely: a) who controlled the media; b) why he or she controlled the media; c) what benefits that might be achieved through the gain of control; and d) which groups that had not been dominant and that had become the object of control. These stages will be implemented in accordance to the needs of the study; therefore, there is a possibility that not all stages will be completely implemented.

\section{Results and Discussion}

In this section, the researcher will elaborate the findings in relation to the two problems that have been stated in the Introduction. Then, the discussions will be based on the two problem statements in relation to the findings.

As having been briefly elaborated in the Introduction, Anies Baswedan won the governor election in the Province of Jakarta Special Capitol by manipulating the sensitive issues around Jakarta and one of these issues is Jakarta Reclamation. During the campaign, Anies promised that he would stop Jakarta Reclamation if he had been elected as the
Governor of Jakarta (Pranandito, 2019; Tim Detikcom, 2019). After two years of his governance, Anies maintains that he has fulfilled his promise on Jakarta Reclamation (Arjawinangun, 2019; Pranandito, 2019). Even one of the political parties that support his candidacy with Sandiaga Uno, namely the Prosperous Justice Party, states that the Governor of Jakarta Special Capitol, Anies Baswedan, has fulfilled his promise in relation to Jakarta Reclamation (Tambun, 2019).

The statements shown in Table 1 confirm that Anies Baswedan has claimed his fulfilment on the cessation of Jakarta Reclamation. At the same time, the idea behind the cessation of Jakarta Reclamation is that the land should be utilized for the greater interest of the people in Jakarta. By doing so, the people in Jakarta might be equally prosperous.

Unfortunately, as provided in Table 2, many people start to question his commitment toward the cessation of Jakarta Reclamation. In fact, most of these people become doubtful toward his commitment since the Provincial Government of Jakarta Special Capitol has issued the building permit for 932 buildings on one of the reclamation island (Pranandito, Kilas Balik Janji Kampanye Anies Baswedan Soal Reklamasi, 2019). Due to this case, many people have been criticizing Anies over and over since they argue that reclamation cessation also means moratorium for the building permit in the island (CNN Indonesia, 2019). 
Table 1. Statements that support the claim of cessation over Jakarta Reclamation

\begin{tabular}{|c|c|c|}
\hline No & Statement & $\begin{array}{l}\text { Translation } \\
\text { (provided by the researcher) }\end{array}$ \\
\hline 1 & $\begin{array}{l}\text { Pemprov DKI Jakarta memulai penghentikan } \\
\text { proyek reklamasi ini dengan menyegel } 932 \\
\text { bangunan di Pulau D pada Kamis, } 7 \text { Juni } 2018 . \\
\text { Mempertegas kebij Pemprov DKI Jakarta } \\
\text { memulai penghentikan proyek reklamasi ini } \\
\text { dengan menyegel } 932 \text { bangunan di Pulau D } \\
\text { pada Kamis, } 7 \text { Juni 2018. Mempertegas } \\
\text { kebijakan ini, Anies Baswedan pada } 26 \\
\text { September } 2018 \text { selanjutnya mengumumkan } \\
\text { pencabutan izin pembangunan } 13 \text { reklamasi } \\
\text { (Arjawinangun, 2019).akan ini, Anies Baswedan } \\
\text { pada } 26 \text { September } 2018 \text { selanjutnya } \\
\text { mengumumkan pencabutan izin pembangunan } \\
13 \text { reklamasi (Arjawinangun, 2019). }\end{array}$ & $\begin{array}{l}\text { In his opinion, the issuance of the } \\
\text { building permit has been in accordance } \\
\text { to the existing procedures. "Building } \\
\text { permit is not about the continuation or } \\
\text { the cessation of the reclamation, but } \\
\text { building permit is about the permit for } \\
\text { the use of reclamation-resulted land by } \\
\text { means of building construction. Whether } \\
\text { the building permit has been issued or } \\
\text { not, the reclamation activities have been } \\
\text { stopped. Therefore, Building Permit and } \\
\text { Reclamation are two different matters," } \\
\text { he said in the information that has been } \\
\text { retrieved in Jakarta, Thursday } \\
(13 / 6 / 2019) \text {. }\end{array}$ \\
\hline 2 & $\begin{array}{l}\text { "Kurang lebih begitu ya. Jadi penghentiannya } \\
\text { sudah memenuhi janji. Nah pemanfaatan lahan } \\
\text { itu adalah untuk masyarakat luas. Itu dua- } \\
\text { duanya terpenuhi janjinya," kata } \\
\text { Abdurrahaman Suhaimi, Senin }(17 / 6 / 2019) \\
\text { (Tambun, 2019). }\end{array}$ & $\begin{array}{l}\text { "It is more or less yes. So, the cessation } \\
\text { has already met his promise. Now, the } \\
\text { utilization of the land is intended to the } \\
\text { public. Both of these promises have } \\
\text { already been met," says Abdurrahaman } \\
\text { Suhaimi, Monday }(17 / 6 / 2019) .\end{array}$ \\
\hline 3 & $\begin{array}{l}\text { Sementara itu, Anies Baswedan bersikukuh } \\
\text { semua kebijakan yang dikeluarkannya sesuai } \\
\text { dengan janji kampanye. Pertama menghentikan } \\
\text { reklamasi dan kedua untuk lahan yang sudah } \\
\text { terjadi dimanfaatkan untuk kepentingan publik } \\
\text { (Tambun, 2019). }\end{array}$ & $\begin{array}{l}\text { In the meantime, Anies Baswedan insists } \\
\text { that all the policies that he has issued are } \\
\text { in accordance to his campaign promises. } \\
\text { First stopping the reclamation and } \\
\text { second the land that has been opened } \\
\text { should be benefitted for public interest. }\end{array}$ \\
\hline
\end{tabular}

Table 2. Statements that display doubtfulness on Anies' commitment toward cessation of Jakarta Reclamation

\begin{tabular}{|c|c|c|}
\hline No & Statement & $\begin{array}{l}\text { Translation } \\
\text { (provided by the researcher) }\end{array}$ \\
\hline 1 & $\begin{array}{l}\text { Walhi menilai langkah Anies saat menyegel } \\
\text { Pulau Reklamasi di Teluk Jakarta tahun lalu } \\
\text { tak berpengaruh. Sebab, proses proyek } \\
\text { reklamasi masih tetap berjalan (Pranandito, } \\
2019 \text { ). }\end{array}$ & $\begin{array}{l}\text { The Indonesian Forum for Environment } \\
\text { thinks that Anies' move when he sealed } \\
\text { the Reclamation Island in Jakarta Bay last } \\
\text { year does not result in any effect. The } \\
\text { reason is that the process of reclamation } \\
\text { project is still taking place. }\end{array}$ \\
\hline 2 & $\begin{array}{l}\text { Ray menyebut tindakan Anies menerbitkan } \\
\text { IMB tersebut telah mengecewakan } \\
\text { pendukungnya. Utamanya, para pendukung } \\
\text { Anies yang memang menolak reklamasi (CNN } \\
\text { Indonesia, 2019). }\end{array}$ & $\begin{array}{l}\text { Ray mentions that Anies' move of issuing } \\
\text { the building permit has made his } \\
\text { supporters disappointed. Especially, his } \\
\text { supporters who truly reject reclamation. }\end{array}$ \\
\hline 3 & $\begin{array}{l}\text { Susan pun mempertanyakan keseriusan Anies } \\
\text { yang sebelumnya ingin menghentikan } \\
\text { reklamasi dan berencana memanfaatkan }\end{array}$ & $\begin{array}{l}\text { Susan thus questions the totality of Anies } \\
\text { who previously planned to stop } \\
\text { reclamation and to benefit a number of }\end{array}$ \\
\hline
\end{tabular}




\begin{tabular}{|c|c|c|}
\hline & $\begin{array}{l}\text { sejumlah pulau reklamasi untuk kepentingan } \\
\text { publik. "Ya, itu, kan, berbanding terbalik } \\
\text { dengan pertanyaan Anies sewaktu debat Dia } \\
\text { bilang 'Apakah segala sesuatu yang berasal } \\
\text { dari masa lalu itu harus dilanjutkan?'. Dia } \\
\text { menanyakan itu ke Ahok saat Ahok } \\
\text { menggunakan Perpres } 52 \text { tahun } 1995 \text { sebagai } \\
\text { dasar reklamasi," ujar Susan (Alaidrus, 2019). }\end{array}$ & $\begin{array}{l}\text { reclamation islands for the public interest. } \\
\text { "This is totally in contradiction to Anies' } \\
\text { question during the debate. He said, } \\
\text { 'Should all aspects from the past be passed } \\
\text { down?' He asked that question to Ahok } \\
\text { when Ahok used the Presidential } \\
\text { Regulation Number } 52 \text { of } 1995 \text { as the basis } \\
\text { of reclamation," Susan says. }\end{array}$ \\
\hline 4 & $\begin{array}{l}\text { "Anies dan Sandiaga sewaktu kampanye } \\
\text { pernah marah, karena penataan teluk Jakarta } \\
\text { harusnya didasarkan pada filosofi yang sama } \\
\text { dengan UU Nomor } 32 \text { Tahun } 2009 \text { tentang } \\
\text { Lingkungan Hidup," kata Ronald kepada } \\
\text { Suara.com, Rabu (13/6/2018). Pasal } 1 \text { UU NO } \\
\text { 32/2009 itu disebutkan, yang menjadi lahan } \\
\text { reklamasi ialah warisan bagi masa depan. } \\
\text { Karenanya, Anies saat itu menentang } \\
\text { keputusan Ahok karena lahan reklamasi teluk } \\
\text { Jakarta digunakan untuk kepentingan } \\
\text { komersial. "Waktu itu Anies marah, karena } \\
\text { tidak ada amdal (analisis mengenai dampak } \\
\text { lingkungan) tidak ada perda, kok ada pulau } \\
\text { palsu. Nah kami sepakat semuanya itu," } \\
\text { ujarnya. Namun, setelah diterbitkannya } \\
\text { pergub pembentukan BKP Reklamasi oleh } \\
\text { Anies, Ronald sebagai pendukung tindakan } \\
\text { Anies saat itu, jelas kecewa (Gunadha, 2018). }\end{array}$ & $\begin{array}{l}\text { "Anies and Sandiaga during the campaign } \\
\text { once hit the ceiling, because the } \\
\text { arrangement of Jakarta Bay should be } \\
\text { based on the same philosophy in Law } \\
\text { Number } 32 \text { of } 2009 \text { Regarding } \\
\text { Environment," Ronald says to Suara.com } \\
\text { on Wednesday (13/6/2018). Article } 1 \text { of } \\
\text { Law Number } 32 \text { of } 2009 \text { Regarding } \\
\text { Environment mentions that the } \\
\text { reclamation land becomes the future } \\
\text { legacy. Therefore, Anies at that time was } \\
\text { against Ahok's decision because the } \\
\text { reclamation land in Jakarta Bay had been } \\
\text { benefitted for commercial interest. "At that } \\
\text { time Anies was angry because there was } \\
\text { not any environmental impact analysis, } \\
\text { there was not any regional regulation and } \\
\text { yet there was a fake island. Well, we totally } \\
\text { agreed on that matter," he says. However, } \\
\text { after the issuance of the governor } \\
\text { regulation on the formation of the Board of } \\
\text { Coordination and Management for } \\
\text { Reclamation by Anies, Ronald, as the } \\
\text { support of Anies' move at that time, } \\
\text { becomes clearly disappointed. }\end{array}$ \\
\hline 5 & $\begin{array}{l}\text { Izin Mendirikan Bangunan yang dikeluarkan } \\
\text { Pemerintah Provinsi DKI Jakarta di pulau } \\
\text { hasil reklamasi di Teluk Jakarta dinilai sebagai } \\
\text { bentuk kepastian politik untuk pengembang } \\
\text { dalam menjalankan bisnisnya. Hal ini } \\
\text { disampaikan Direktur Eksekutif Wahana } \\
\text { Lingkungan Hidup (Walhi) Jakarta Tubagus } \\
\text { Soleh Ahmadi, Minggu (23/6) di Jakarta. } \\
\text { "Pemprov DKI sedang memberikan kepastian- } \\
\text { kepastian politik kepada pengembang untuk } \\
\text { melakukan praktik bisnis di Jakarta," kata } \\
\text { Tubagus (CNN Indonesia, 2019). }\end{array}$ & $\begin{array}{l}\text { The Building Permit that has been issued } \\
\text { by the Provincial Government of Jakarta } \\
\text { Special Capitol in the reclamation island of } \\
\text { Jakarta Bay is considered to be the form of } \\
\text { political certainty for the developers in } \\
\text { running their business. This statement was } \\
\text { delivered by the Executive Director of the } \\
\text { Indonesian Forum for Environment } \\
\text { Jakarta Tubagus Soleh Ahmadi on Sundary } \\
(23 / 6) \text { in Jakarta. "The Provincial } \\
\text { Government of Jakarta Special Capitol has } \\
\text { been granting political certainties to the } \\
\text { developers for running their business } \\
\text { practice in Jakarta," Tubagus says. }\end{array}$ \\
\hline
\end{tabular}

Looking at this situation, Anies started to respond the statements from the people who had questioned his commitment toward the cessation of Jakarta Reclamation. Through the statements in the following table, Anies strives to ensure the public, especially those who have questioned his commitment, that the cessation of Jakarta Reclamation will be completely executed. 
Table 3. Statements that display Anies' efforts to convince the public about his commitment toward the cessation of Jakarta Reclamation

\begin{tabular}{|c|c|c|}
\hline No & Statement & $\begin{array}{c}\text { Translation } \\
\text { (provided by the researcher) }\end{array}$ \\
\hline 1 & $\begin{array}{l}\text { Menurutnya, penerbitan IMB tersebut sudah } \\
\text { sesuai dengan prosedur yang ada. "IMB ini } \\
\text { bukan soal reklamasi jalan atau berhenti, } \\
\text { tapi IMB adalah soal izin pemanfaatan } \\
\text { lahan hasil reklamasi dengan cara } \\
\text { mendirikan bangunan. Dikeluarkan atau } \\
\text { tidak IMB, kegiatan reklamasi telah } \\
\text { dihentikan. Jadi, IMB dan Reklamasi adalah } \\
\text { dua hal yang berbeda," katanya dalam } \\
\text { keterangan yang diterima di Jakarta, Kamis } \\
(13 / 6 / 2019) \text { (Redaksi WE Online, 2019) }\end{array}$ & $\begin{array}{l}\text { In his opinion, the issuance of the building } \\
\text { permit has been in accordance to the } \\
\text { existing procedures. "Building permit is not } \\
\text { about the continuation or the cessation of } \\
\text { the reclamation, but building permit is } \\
\text { about the permit for the use of reclamation- } \\
\text { resulted land by means of building } \\
\text { construction. Whether the building permit } \\
\text { has been issued or not, the reclamation } \\
\text { activities have been stopped. Therefore, } \\
\text { Building Permit and Reclamation are two } \\
\text { different matters," he said in the } \\
\text { information that has been retrieved in } \\
\text { Jakarta, Thursday (13/6/2019). }\end{array}$ \\
\hline 2 & $\begin{array}{l}\text { "Kini Kegiatan reklamasi itu telah } \\
\text { dihentikan. Semua izin reklamasi telah } \\
\text { dicabut. Ada } 13 \text { pulau tidak bisa diteruskan } \\
\text { dan dibangun. Ada } 4 \text { kawasan pantai yang } \\
\text { sudah terbentuk sebagai hasil reklamasi di } \\
\text { masa lalu. Faktanya itu sudah jadi daratan," } \\
\text { tegasnya (Redaksi WE Online, 2019). }\end{array}$ & $\begin{array}{l}\text { Now the reclamation activities have been } \\
\text { stopped. There are } 13 \text { islands that may not } \\
\text { be developed anymore. There are } 4 \text { coastal } \\
\text { areas that have been formed due to the } \\
\text { reclamation activities in the past. The fact is } \\
\text { that these areas have become property," he } \\
\text { said. }\end{array}$ \\
\hline 3 & $\begin{array}{l}\text { IMB ini bukan soal reklamasi jalan atau } \\
\text { berhenti, tapi IMB adalah soal izin } \\
\text { pemanfatan lahan hasil reklamasi dengan } \\
\text { cara mendirikan bangunan. Dikeluarkan } \\
\text { atau tidak IMB, } \\
\text { kegiatan reklamasi telah dihentikan. Jadi, } \\
\text { IMB dan Reklamasi adalah dua hal yang } \\
\text { berbeda (Pranandito, 2019). }\end{array}$ & $\begin{array}{l}\text { Building permit is not about the } \\
\text { continuation or the cessation of the } \\
\text { reclamation, but building permit is about } \\
\text { the permit for the use of reclamation- } \\
\text { resulted land by means of building } \\
\text { construction. Whether the building permit } \\
\text { has been issued or not, the reclamation } \\
\text { activities have been stopped. Therefore, } \\
\text { Building Permit and Reclamation are two } \\
\text { different matters. }\end{array}$ \\
\hline 4 & $\begin{array}{l}\text { Semua kebijakan yang kita buat sesuai janji } \\
\text { kami, yaitu: } \\
\text { 1. Menghentikan reklamasi } \\
\text { 2. Untuk lahan yang sudah jadi } \\
\text { dimanfaatkan untuk kepentingan publik. } \\
\text { Itu lah janji kami, dan kami konsisten } \\
\text { memegang dan melaksanakan janji itu. } \\
\text { Bayangkan bila kami tidak menghentikan } \\
\text { reklamasi, maka kini sudah akan terbangun } \\
\text { 17 pulau, seluas Kabupaten Sukabumi, di } \\
\text { TelukJakarta (Pranandito, 2019). }\end{array}$ & $\begin{array}{l}\text { All policies that we have made are already in } \\
\text { accordance to our promises namely: } \\
\text { 1. Stop reclamation } \\
\text { 2. Benefit the land that has been formed for } \\
\text { the public interest } \\
\text { That's our promise, and we consistently } \\
\text { hold and keep our promise. Can you imagine } \\
\text { if we do not stop the reclamation there will } \\
\text { already have been } 17 \text { islands, as wide as the } \\
\text { Regency of Sukabumi, in Jakarta Bay. }\end{array}$ \\
\hline 5 & $\begin{array}{l}\text { Anies menjelaskan, saat kampanye dia tak } \\
\text { cuma berjanji akan menghentikan reklamasi } \\
\text { tapi juga memanfaatkan pulau reklamasi }\end{array}$ & $\begin{array}{l}\text { Anies explains, during the campaign he did } \\
\text { not only promise to stop the reclamation } \\
\text { but also to benefit the reclamation island }\end{array}$ \\
\hline
\end{tabular}




\begin{tabular}{|c|c|c|}
\hline & $\begin{array}{l}\text { yang sudah terbentuk untuk kepentingan } \\
\text { masyarakat Jakarta secara luas. Karena itu ia } \\
\text { pada 4 Juni 2018, dia membentuk Badan } \\
\text { Koordinasi Pengelolaan Reklamasi Pantai } \\
\text { Utara Jakarta. Hasil audit oleh Badan ini, } 26 \\
\text { September } 2018 \text { Pemerintahan Provinsi DKI } \\
\text { mencabut } 13 \text { izin proyek reklamasi dari } \\
\text { sejumlah pengembang karena tidak } \\
\text { melaksanakan kewajibannya. Sejak itu proyek } \\
\text { reklamasi dihentikan (Dariyanto, 2019). }\end{array}$ & $\begin{array}{l}\text { that had been formed into the public } \\
\text { interest of the Jakarta society. Therefore, } \\
\text { on June } 4^{\text {th }}, 2018 \text {, he established the } \\
\text { Coordinating Body of Northern Jakarta } \\
\text { Coast Reclamation. Departing from the } \\
\text { audit results of the Coordinating Body on } \\
\text { September } 26^{\text {th }} 2018 \text {, the Provincial } \\
\text { Government of Jakarta Special Capitol } \\
\text { revoked the permission of } 13 \text { reclamation } \\
\text { projects from a number of developers } \\
\text { because the developers do not deliver } \\
\text { their responsibility. Ever since then, the } \\
\text { reclamation project has been stopped. }\end{array}$ \\
\hline 6 & $\begin{array}{l}\text { Terkait IMB yang diterbitkan, lelaki kelahiran } \\
\text { Kuningan, } 7 \text { Mei 1969, ini menyatakan ada } \\
\text { peraturan dan perjanjian antara Pemprov } \\
\text { DKI dengan pengembang yang dibuat } \\
\text { sebelum dia menjabat. Pada } 25 \text { Oktober } 2016 \\
\text { terbit Pergub Nomor } 206 \text { tahun 2016. Pergub } \\
\text { itu mengatur soal tata ruang dan tata } \\
\text { wilayah di Pantai Maju. Setelah itu lahir } \\
\text { Perjanjian Kerjasama antara pengembang } \\
\text { dengan Pemprov DKI pada } 11 \text { Agustus 2017, } 2 \\
\text { dan } 5 \text { Oktober } 2017 \text { (Dariyanto, 2019). }\end{array}$ & $\begin{array}{l}\text { In relation to the building permit that has } \\
\text { been issued, the man who was born in } \\
\text { Kuningan on May } 7^{\text {th }}, 1969 \text {, states that } \\
\text { there are regulations and agreements } \\
\text { between the Provincial Government of } \\
\text { Jakarta Special Capitol and the developers } \\
\text { that have been made prior to his } \\
\text { governance. In Octobers } 25^{\text {th }}, 2016 \text {, the } \\
\text { Governor Regulation Number } 206 \text { of } 2016 \\
\text { was issued. This Governor Regulation } \\
\text { deals with the arrangement of the spatial } \\
\text { and the regional layout. Afterward, an } \\
\text { agreement between the developers and } \\
\text { the Provincial Government of Jakarta } \\
\text { Special Capitol was achieved on August } \\
\text { 11 } \\
\text { th, October } 2^{\text {nd }} \text { and October } 5^{\text {th }} \text {. }\end{array}$ \\
\hline 7 & $\begin{array}{l}\text { Anies Baswedan mengatakan, pembongkaran } \\
\text { pulau hasil reklamasi di Teluk Jakarta akan } \\
\text { menyebabkan kerusakan lingkungan yang } \\
\text { luar biasa. Karena itu, Pemprov DKI Jakarta } \\
\text { tidak akan membongkar daratan hasil } \\
\text { reklamasi yang sudah dibangun, meskipun } \\
\text { proyek reklamasi dihentikan. "Kenapa tidak } \\
\text { dibongkar? Kerusakan lingkungannya hebat } \\
\text { sekali. Bayangkan, lahan bisa besarnya } \\
\text { sampai } 350 \text { hektar, itu tanahnya mau } \\
\text { dikemanakan bila dibongkar. Jadi, } \\
\text { kerusakannya akan luar biasa," kata Anies } \\
\text { dalam program AIMAN yang tayang di } \\
\text { Kompas TV, Senin (1/7/2019) malam (Sari, } \\
\text { 2019). }\end{array}$ & $\begin{array}{l}\text { Anise Baswedan said that the dismantling } \\
\text { of the reclamation-resulted islands in } \\
\text { Jakarta Bay will cause enormous } \\
\text { environmental damage. Therefore, the } \\
\text { Provincial Government of Jakarta Special } \\
\text { Capitol will not dismantle the already } \\
\text { reclamated land although the reclamation } \\
\text { project has been stopped. "Why it } \\
\text { shouldn't be dismantled?" the } \\
\text { environmental damage will be enormous. } \\
\text { Can you imagine what should be we do if } \\
\text { this } 350 \text { hectare-width area is dismantled? } \\
\text { Therefore, then environmental damage } \\
\text { will be enormous," Anies said in AIMAN } \\
\text { program aired on Kompas TV, Monday } \\
\text { (1/7/2019) night. }\end{array}$ \\
\hline
\end{tabular}

Unfortunately, his efforts to convince the public that he still holds his commitment on the cessation of Jakarta Reclamation have not returned in any significant impact. In fact, the situation becomes worse because the State Administrative of Jakarta has decided that Anies Baswedan should process the renewal permit for the reclamation of Island $\mathrm{H}$ in Jakarta Bay (Sari, SK Dibatalkan, Anies Diwajibkan Proses Perpanjangan Izin Reklamasi Pulau H, 2019).The statements are shown in Table 4. 
Table 4. Statements that display the contradiction between the efforts of Anies Baswedan in showing his commitment on the cessation of Jakarta Reclamation and the facts that have been found in the field

\begin{tabular}{|c|c|c|}
\hline No & Statement & $\begin{array}{l}\text { Translation } \\
\text { (provided by the researcher) }\end{array}$ \\
\hline 1 & $\begin{array}{l}\text { Pengadilan Tata Usaha Negara (PTUN) } \\
\text { Jakarta mewajibkan Gubernur DKI } \\
\text { Jakarta Anies Baswedan memproses izin } \\
\text { perpanjangan surat keputusan (SK) } \\
\text { gubernur soal pemberian izin reklamasi } \\
\text { Pulau H di TelukJakarta. Hal itu tertuang } \\
\text { dalam putusan PTUN Jakarta atas } \\
\text { perkara nomor 24/G/2019/PTUN.JKT } \\
\text { yang diputuskan pada 9 Juli } 2019 . \\
\text { "Mewajibkan tergugat untuk memproses } \\
\text { izin perpanjangan Surat Keputusan } \\
\text { Gubernur Provinsi DKI Jakarta Nomor } \\
2637 \text { Tahun } 2015 \text { tentang Pemberian Izin } \\
\text { Pelaksanaan Reklamasi Pulau H Kepada } \\
\text { PT Taman Harapan Indah sesuai } \\
\text { peraturan yang berlaku," demikian bunyi } \\
\text { putusan majelis hakim PTUN Jakarta } \\
\text { sebagaimana dikutip Kompas.com dari } \\
\text { situs web resmi PTUN Jakarta, ptun- } \\
\text { jakarta.go.id, Senin (29/7/2019). Dalam } \\
\text { putusan tersebut, PTUN Jakarta juga } \\
\text { membatalkan SK Anies terkait } \\
\text { pembatalan izin reklamasi Pulau H di } \\
\text { TelukJakarta (Sari, 2019). }\end{array}$ & $\begin{array}{l}\text { The Civil Court of Justice Jakarta has } \\
\text { commanded the Governor of Jakarta Special } \\
\text { Capitol to process the renewal permit on the } \\
\text { Governor Decree for Reclamation Permit in H } \\
\text { Island of Jakarta Bay. This command has been } \\
\text { issued on the decision of the Civil Court of } \\
\text { Justice Jakarta Number } \\
24 / G / 2019 / \text { PTUN.JKT on July 9th, } 2019 \text {. "Has } \\
\text { commanded the defendant to process the } \\
\text { renewal perform on the Governor of Jakarta } \\
\text { Special Capitol Decree Number } 2637 \text { of } 2015 \\
\text { on the Issuance of Reclamation in H Island to } \\
\text { Taman Harapan Indah Company in } \\
\text { accordance to the governing regulations," this } \\
\text { is the verdict from the panel of judges in the } \\
\text { Civil Court of Justice Jakarta as having been } \\
\text { quoted by Kompas.com from the official } \\
\text { website of the Civil Court of Justice Jakarta, } \\
\text { ptun-jakarta.go.id, on Monday (29/7/2019). } \\
\text { In this decision, the Civil Court of Justice } \\
\text { Jakarta has also revoked the Decree issued by } \\
\text { Anies in relation to the cancellation of } \\
\text { reclamation permit for H Island in Jakarta } \\
\text { Bay. }\end{array}$ \\
\hline 2 & $\begin{array}{l}\text { Menanggapi putusan PTUN Jakarta, Anies } \\
\text { menyebut Pemprov DKI Jakarta akan } \\
\text { terus melawan para pengembang yang } \\
\text { akan melanjutkan proyek reklamasi di } \\
\text { Teluk Jakarta. "Intinya, kami tidak akan } \\
\text { mundur. Kami menghormati pengadilan, } \\
\text { tapi kami akan terus melawan } \\
\text { pengembang yang berencana } \\
\text { melanjutkan reklamasi," ujar Anies di GOR } \\
\text { Rorotan, Jakarta Utara, Senin kemarin. } \\
\text { Pemprov DKI Jakarta, kata Anies, akan } \\
\text { terus berupaya menghentikan reklamasi } \\
\text { di Teluk Jakarta. Karena itu, Anies } \\
\text { memastikan Pemprov DKI akan } \\
\text { menempuh langkah hukum. "Sikap kami } \\
\text { tidak berubah, kami akan terus dan kami } \\
\text { akan menggunakan jalur hukum juga } \\
\text { untuk menghentikan reklamasi," kata } \\
\text { Anies. Langkah hukum yang dimaksud } \\
\text { Anies ialah mengajukan banding ke } \\
\text { Pengadilan Tinggi Tata Usaha Negara } \\
\text { (PTTUN) Jakarta (Sari, 2019). }\end{array}$ & $\begin{array}{l}\text { Responding the verdict by the Civil Court of } \\
\text { Justice Jakarta, Anies states that the } \\
\text { Provincial Government of Jakarta Special } \\
\text { Capitol will keep fighting the developers who } \\
\text { will continue the reclamation project in the } \\
\text { Jakarta Island. "The main point is that we will } \\
\text { not hold back. We respect the verdict of the } \\
\text { Court, but we will keep fighting the } \\
\text { developers who plan to continue the } \\
\text { reclamation," Anies said in Rorotan Sports } \\
\text { Hall, North Jakarta, last Monday. Therefore, } \\
\text { Anies ensures that the Provincial Government } \\
\text { of Jakarta Special Capitol will take legal } \\
\text { action. "Our attitude will not change, we will } \\
\text { keep going on and we will take legal action as } \\
\text { well in order to stop the reclamation," Anies } \\
\text { said. The legal action intended by Anies is to } \\
\text { propose an appeal to the Civil Court of Justice } \\
\text { Jakarta. }\end{array}$ \\
\hline
\end{tabular}




\begin{tabular}{|c|c|c|}
\hline 3 & $\begin{array}{l}\text { Anies menambahkan gedung yang sudah } \\
\text { berdiri di pulau reklamasi tersebut sudah } \\
\text { sesuai dengan Pergub Nomor } 206 \text { Tahun } \\
\text { 2016. Di samping itu, pengembang telah } \\
\text { melakukan putusan pengadilan dan } \\
\text { membayar denda. Karena itu, kata dia, } \\
\text { tidak ada alasan bagi Pemprov Jakarta } \\
\text { untuk tidak menerbitkan IMB (Madrim, } \\
\text { 2019). }\end{array}$ & $\begin{array}{l}\text { Anies adds that the buildings that have been } \\
\text { constructed in the reclamation islands are } \\
\text { already in accordance to the Governor } \\
\text { Regulation Number } 206 \text { of } 2016 \text {. In addition, } \\
\text { the developers have also executed the verdict } \\
\text { of the Court and have settled the fine. } \\
\text { Therefore, he says, there is not any reason for } \\
\text { the Provincial Government of Jakarta Special } \\
\text { Capitol to not issue the building permit. }\end{array}$ \\
\hline 4 & $\begin{array}{l}\text { Gubernur DKI Jakarta Anies Baswedan } \\
\text { mengatakan, bangunan-bangunan yang } \\
\text { berdiri di pulau hasil reklamasi statusnya } \\
\text { legal. Pemprov DKI diketahui telah } \\
\text { menerbitkan izin mendirikan bangunan } \\
\text { (IMB) untuk bangunan-bangunan itu. } \\
\text { "Sekarang pertanyaannya, apakah } \\
\text { bangunan di situ (pulau hasil reklamasi) } \\
\text { legal? Ternyata bangunan di situ legal," } \\
\text { ujar Anies dalam program AIMAN yang } \\
\text { ditayangkan Kompas TV, Senin } \\
\text { (1/7/2019) malam. Anies menjelaskan, } \\
\text { sertifikat hak pengelolaan lahan (HPL) } \\
\text { pulau reklamasi atas nama Pemprov DKI } \\
\text { Jakarta terbit pada 2017. Kemudian, } \\
\text { pengembang mengantongi sertifikat hak } \\
\text { guna bangunan (HGB). Penerbitan HGB } \\
\text { itu, kata Anies, merujuk pada Peraturan } \\
\text { Gubernur Nomor 206 Tahun 2016 tentang } \\
\text { Panduan Rancang Kota } \\
\text { Pulau Reklamasi (Sari, 2019). }\end{array}$ & $\begin{array}{l}\text { The Governor of Jakarta Special Capitol Anies } \\
\text { Baswedan says the buildings that have been } \\
\text { constructed on the reclamation-resulted } \\
\text { island have legal status. The Provincial } \\
\text { Government of Jakarta Special Capitol is } \\
\text { discovered to have issued the building permit } \\
\text { for those buildings. "Now, the question is } \\
\text { whether the buildings in that area } \\
\text { (reclamation-resulted island) are legal or not. } \\
\text { It turns out that these buildings are legal," } \\
\text { Anies said in the program AIMAN aired on } \\
\text { Kompas TV, Monday (1/7/2019) evening. } \\
\text { Anies explains that the certificate of Property } \\
\text { Management Rights for the reclamation } \\
\text { island on the behalf of the Provincial } \\
\text { Government of Jakarta Special Capitol has } \\
\text { been issued in } 2017 \text {. Then, the developers } \\
\text { have been provided with the certificate of } \\
\text { Building Use Rights. The issuance of the } \\
\text { Building Use Rights has referred to the } \\
\text { Governor Regulation Number } 2016 \text { of } 2016 \\
\text { with Regards to the City Design Guide in } \\
\text { Reclamation Island. }\end{array}$ \\
\hline
\end{tabular}

As having been suggested in the beginning of the section, the discussions will be based on the two problem statements in relation to the findings. Each problem statement will be elaborated below.

\section{How Anies Baswedan Has Shown His Commitment for Stopping Jakarta Reclamation}

As having been implied in the literary review, in order to analyse the statements around Anies Baswedan and his commitment on the cessation of Jakarta Reclamation, the researcher will apply the Fairclough analysis. The dimension of the Fairclough analysis that will be implemented in the study is the text analysis because the researcher would like to focus on the statements around the commitment of Jakarta Reclamation cessation as part of his political commitment in the campaign. Then, departing from the statements that have been gathered around Anies Baswedan and the issue of Jakarta Reclamation, there are several points that might be gathered. First, Anies Baswedan has indeed manipulated the issue of Jakarta Reclamation as one of his political weapons during the campaign by promising that he shall cease the Jakarta Reclamation. Second, Anies Baswedan has shown his commitment toward the cessation of Jakarta Reclamation by sealing 932 buildings on Island D. Third, despite the cessation, the Provincial Government of Jakarta Special Capitol has issued the building permit for a number of buildings in the reclamation islands. Fourth, due to the issuance of the building permit, many people who used to be his supporters now turn out to be his opponents by 
questioning his commitment toward the cessation of Jakarta Reclamation. Fifth, in response to the situation, Anies strives to convince the public that he still holds his commitment toward the cessation of Jakarta Reclamation. In his opinion, cessation of reclamation and issuance of building permit are two different things and not to mention, the issuance of the building permit is already in accordance to the legal procedures. Seventh, the dispute between Anies and the proponents of the cessation becomes more intense due to the decree issued by the Civil Court of Justice, which has commanded Anies to continue the reclamation process.

Looking at the points that have been elaborated above, the attitude of Anies Baswedan toward the cessation of Jakarta Reclamation might be described. In the very first place, it might be inferred that Anies Baswedan is just an opportunistic person. Returning to the general election for DKI-1, it was almost impossible for Anies to get over the other candidate namely Basuki Tjahaja Purnama or known as Ahok. Therefore, he tried to elicit public attention by manipulating one of the detrimental issues for Ahok and one of these issues was Jakarta Reclamation. Not to mention, the popularity of Ahok itself was decreased due to the blasphemy accusation that had been charged to him. As a result, the public in Jakarta at that time, especially those who hated Ahok, started to support Anies Baswedan and just in a nick of time Anies gained significant support.

As one might have predicted, with the increasing support that he had, Anies Baswedan finally won the general election. Thus, as he has promised, Anies Baswedan finally issued his decree that later ceased the reclamation process in Jakarta Bay. The peak of this issue has been the seal of 932 buildings in Island $\mathrm{D}$, one of the islands that have been resulted from the reclamation efforts. At a glance, it is apparent that Anies Baswedan has already fulfilled his political promise in relation to the cessation of Jakarta Reclamation. However, this is just the beginning of another problem. Indeed, Anies Baswedan has ceased the Jakarta Reclamation but several weeks later he has issued the building permit for a number of buildings in the other reclamation island. Certainly, this decision has triggered his supporters, especially from the environmental activists to start questioning his commitment on the cessation of Jakarta Reclamation. Even some of his supporters say that Anies and Ahok are no different since both of them let the process of Jakarta Reclamation continue.

In addition, it might be inferred that Anies Baswedan does not have a proper understanding in relation to the legal system. This statement might be traced into his decision to use the Governor Regulation Number 206 of 2016. In his opinion, this regulation might be used for issuing the building permit to a number of buildings in the reclamation island since it has already been stipulated by the previous governor namely Ahok. On the contrary, Ahok states that this governor regulation might not be used as the foundation for issuing the building permit since it does not have strong and sound legal capacity to serve as the legal foundation for the issuance of the permit. This dispute is the beginning of a number of criticisms directed toward Anies over his commitment to cease the Jakarta Reclamation. In response to the criticisms, Anies strives to convince the public that he still holds his commitment in ceasing the Jakarta Reclamation. As having been asserted, he has shown his commitment by sealing the 932 buildings in Island D. Then, he further states that cessation of Jakarta Reclamation and issuance of building permit are two different things. With regards to the issuance of the building permit, he asserts that this decision is already in accordance to the procedures since there has been an agreement between the developers and the previous governor and this agreement thus should be executed.

Last but not the least, it might also be inferred that Anies Baswedan does not have sufficient understanding on the benefits of reclamation. As the public have understood well, Jakarta is lower than the sea level and therefore there should be a kind of fortress that might avoid Jakarta from totally being under the sea level. This is where reclamation plays its role: reclamation aims at opening new land to serve as a kind of fortress so that the occurrence of rob flood in Jakarta, 
specifically, might be decreased and finally eliminated. Unfortunately, many people, especially the environmental activists, have gone against this idea because they are afraid that the reclamation might destroy the marine ecosystem around the area in reclamation. Once again, since Anies is opportunistic, he made use of this issue by turning it into a political charge so that he might gain significant victory over Ahok and he did it.

In sum, with regard to the commitment toward the cessation of Jakarta Reclamation, it might be stated that Anies Baswedan has not shown his genuine commitment toward the cessation of Jakarta Reclamation. In fact, it might be inferred that Anies Baswedan is opportunistic since he has only manipulated the issue of Jakarta Reclamation for gaining victory during the run of general election for DKI-1. This action suits well into the famous line by Niccolò Machiavelli: "The end justifies the means." If one wants to truly fulfil his desire, then he should benefit all the necessary means at all cost.

\section{How People Might Take Critical Attitude toward the Promise of a Political Figure}

In order to avoid similar situation, namely being used by a politician in order to win the vote, there are several ways that one might apply. One of these ways is implementing a framework known as critical paradigm that consists of four questions namely: a) who controlled the media; b) why he or she controlled the media; c) what benefits that might be achieved through the gain of control; and d) which groups that had not been dominant and that had become the object of control. However, for the case of Anies Baswedan and his commitment toward the cessation of Jakarta Reclamation, the questions posed by the critical media approach should be modified. The reason behind the modification is that with regards to political figure the analysis should be beyond the news items since news media might have bias attitude toward the given political figure. By doing so, it is believed that more objective opinion might be made and thus the public might use their vote in a more appropriate manner.
As a result, the questions that have been proposed should be changed in order to accommodate the objective of the study. Thus, the very first question will be who is portrayed by the media. Specific to the topic of the study, the figure that has been portrayed is Anies Baswedan. Indeed, Anies has promised that he shall cease the Jakarta Reclamation once after he has officially won the general election. If one wants to be critical over his promise in the campaign, he or she should identify the urgency of ceasing the Jakarta Reclamation. Furthermore, he or she should also consider whether the cessation of Jakarta Reclamation will bring about more positive or more negative impacts to the public. If the reclamation brings about more positive impact than the negative impact, then the Jakarta Reclamation should have never been stopped. Moreover, one should ensure as well whether the promise to cease the Jakarta Reclamation that Anies Baswedan has made is just a lip service or not. Returning to the present situation, it is clear that his commitment toward the cessation of Jakarta Reclamation is just a mere political lip service. Then, the second question that might be posed with regards to the topic is why the political figure, specifically Anies Baswedan, has been portrayed in the media. This statement might be traced back into the struggle for DKI-1. At that time, the first round of the general election for DKI-1 involved three pairs of candidates namely Anies Baswedan-Sandiaga Uno, Basuki Tjahaya Purnama-Djarot Saiful Hidayat and Agus Harimurti Yudhoyono-Sylviana Murni. In the first round, Anies Baswedan and Sandiaga Ugo were underestimated in comparison to the other two pairs of candidates. However, the table turned around when it came to the second round of the general election. Anies Baswedan and Sandiaga Uno suddenly gained significant support over his rivalry with Basuki Tjahaja Purnama and Djarot Saiful Hidayat. Apart of the strong support from the Moslem hardliners, Anies Baswedan made use of the environmental issue namely the case of Jakarta Reclamation. In fact, he turned the case of Jakarta Reclamation into his ultimate political weapon by promising that he shall stop Jakarta Reclamation once he has been elected officially as the Governor of Jakarta 
Special Capitol and thus he started gaining the significant support from the environmental activists. In relation to the recent situations, people can see that he actually has not fully fulfilled his commitment on the cessation of Jakarta Reclamation since he has issued the building permit for a number of buildings in one of the reclamation islands under the appropriate legal procedures.

Next, the third question that might be posed is what benefits that might be achieved through the manipulation of a certain issue. The benefit is already clear: gaining significant support from any party that goes against the political opponent. Specific to the case of Jakarta Reclamation, as one might clearly see, Anies has manipulated the case by promising that he shall cease the Jakarta Reclamation and he even further stated that he shall use the reclamation island for the public interest of the people in Jakarta. Consequently, Anies has gained significant support from the environmental activists that protest the efforts of Jakarta Reclamation. Unfortunately, it is too late that these activists have only been benefitted by Anies Baswedan to smooth his way toward DKI-1. Indeed, Anies has convinced the public that he has fulfilled his promise to stop the Jakarta Reclamation by sealing 932 buildings from Island $\mathrm{D}$ through one of his decrees but several moments later he issued the building permit for a number of buildings in one of the reclamation islands under the appropriate legal procedure. This is the reason why the environmental activists have decided to question his commitment toward the cessation of Jakarta Reclamation.

Last but not the least, the fourth or the final question that might be posed is which group that has been manipulated by the action of a political figure. Certainly, the group that has been benefitted by the manoeuvre made by Anies Baswedan in this regard is the environmental activists. Indeed, it should be admitted that Anies Baswedan is a smart and cunning politician since the principle by Machiavelli, "The end justifies the means," has been fully applied by him. In order to expand the number of supports for his vote, he strived to benefit a number of issues and one of the issues was the environmental issue namely the Jakarta Reclamation. Then, he boldly claimed that he shall cease the Jakarta Reclamation once he has been officially elected as the Governor of Jakarta Special Capitol. Indeed, Anies Baswedan finally won the election and he thus has kept his commitment by ceasing the Jakarta Reclamation. Unfortunately, several moments after the cessation Anies issued the building permit for a number of buildings in one of the reclamation islands. It is this decision that has made the environmental activists to perceive that they have just been manipulated for his political intention.

\section{Conclusion}

Departing from the findings and the discussions in the previous sections, several conclusions might be drawn. First of all, Anies Baswedan has not fully committed to cease the Jakarta Reclamation. Indeed, he has sealed 932 buildings in Island $\mathrm{D}$ but several moments later he has issued the building permit for a number of buildings in one of the reclamation islands under the appropriate legal procedures. As a result, his supporters, especially those from the group of environmental activists, start to question his commitment toward the cessation of Jakarta Reclamation. Second, by modifying the questions posed in the critical paradigm, people might start being critical toward any political figure, especially the opportunistic figure that will use any means necessary for gaining his political intention done. Then, the questions from the critical paradigm that have been modified is as follows: (a) who is portrayed by the media; (b) why the political figure has been portrayed in the media; (c) what benefits that might be achieved through the manipulation of certain issue; and (d) which group that has been manipulated by the action of a political figure. Last but not the least, despite the findings and the discussions, the researcher still perceives several limitations within the conduct of the study and one of the limitations lies in the application of the four questions from the critical paradigm that has been modified. Therefore, in order to pursue the validity of the four questions, there should be more empirical research on the four questions so that these questions might be finally validated 
and be used for being critical to the political figures especially nearby the time of the general election since there might be many opportunistic political figures that manipulate certain group of people for exerting their political intentions and agenda.

\section{References}

Administrator. (2016, August 9). Pengertian Reklamasi, Tujuan, dan Sistem Reklamasi. Retrieved from http://trtb.pemkomedan.go.id/artikel -821-pengertian-reklamasi-tujuandan-sistem-reklamasi.html\#

Alaidrus, F. (2019, June 20). Penerbitan IMB Pulau Reklamasi Tak Sejalan Janji Kampanye Anies. Retrieved from https://tirto.id/penerbitan-imbpulau-reklamasi-tak-sejalan-janjikampanye-anies-ecJp

Arjawinangun, K. B. (2019, June 26). 7 Janj Kampane Anies yang Berhasil Diwujudkan. Retrieved from https://metro.sindonews.com/read/1 414546/171/7-janji-kampanye-aniesyang-berhasil-diwujudkan1561443862

CNN Indonesia. (2019, June 24). Janji Anies Soal Reklamasi Disebut Jauh dari Bayangan Publik. Retrieved from https://www.cnnindonesia.com/nasi onal/20190623175923-20405703/janji-anies-soal-reklamasidisebut-jauh-dari-bayangan-publik

CNN Indonesia. (2019, June 23). Walhi Nilai IMB Reklamasi Kepastian Berbisnis Pengembang. Retrieved from https://www.cnnindonesia.com/nasi onal/20190623151542-20405666/walhi-nilai-imb-reklamasikepastian-berbisnis-pengembang?

Dariyanto, E. (2019, June 28). Anies Jawab Terbitnya IMB Reklamasi dan Tuduhan
Ingkar Janji. Retrieved from https://news.detik.com/berita/d4603344/anies-jawab-terbitnya-imbreklamasi-dan-tuduhan-ingkar-janji

Eriyanto. (2001). Analisis Wacana: Pengantar Analisis Teks Media. Yogyakarta: LKiS.

Fairclough, N. (1995). Critical Discourse Analysis: The Critical Study of Language. New York: Longman.

Gunadha, R. (2018, June 13). Terbitkan Pergub Reklamasi, Walhi: Anies Ingkar Janji Kampanye. Retrieved from https://www.suara.com/news/2018/ 06/13/171730/terbitkan-pergubreklamasi-walhi-anies-ingkar-janjikampanye

Hanzel, M. (2011, March 9). Partai Politik di Indonesia (dan Namanya dalam Bahasa Inggris). Retrieved from https://matthewhanzel.com/2011/03 /09/partai-politik-di-indonesia-dannamanya-dalam-bahasa-inggris/

Madrim, S. (2019, June 22). Langkah Mundur Gubernur Jakarta Hentikan Reklamasi. Retrieved from: https://www.voaindonesia.com/a/lan gkah-mundur-gubernur-jakartahentikan-reklamasi/4969702.html

Mubarok, \& Wulandari, D. (2018). Konstruksi Media dalam Pemberitaan Kontra Terorisme di Indonesia. INFORMASI: Kajian Ilmu Komunikasi, 139-152.

OECD. (2001, September 25). Glossary of Statistical Terms. Retrieved from https://stats.oecd.org/glossary/detail .asp?ID=1496

Pranandito, G. A. (2019 , June 18). Soal Reklamasi Jakarta, WALHI: Anies Gak Ada Bedanya dengan Ahok! Retrieved from https://www.idntimes.com/ news/indonesia/gregoriuspranandito/soal-reklamasi-jakartawalhi-anies-gak-ada-bedanya-denganahok/full 
Pranandito, G. A. (2019, June 19). Ini Jawaban Lengkap Anies Baswedan Soal Reklamasi Teluk Jakarta. Retrieved from https://www.idntimes.com/ news/indonesia/gregoriuspranandito/jawaban-lengkap-aniesbaswedan-soal-reklamasi-telukjakarta/full

Pranandito, G. A. (2019, June 17). Kilas Balik Janji Kampanye Anies Baswedan Soal Reklamasi. Retrieved from https://www.idntimes.com/news/ind onesia/gregorius-pranandito/kilasbalik-janji-kampanye-aniesbaswedan-soal-reklamasi/full

Redaksi WE Online. (2019, June 14). Akui Terbitkan IMB di Pulau Reklamasi, Anies Bilang: Sesuai Janji Kampanye. Retrieved September 24, 2019, from https://www.wartaekonomi.co.id/rea d231906/akui-terbitkan-imb-dipulau-reklamasi-anies-bilang-sesuaijanji-kampanye.html

Sari, N. (2019, July 2). Anies: Bangunan di Pulau Reklamasi Legal. Retrieved September 25, 2019, from https://megapolitan. kompas.com/read/2019/07/02/0641 5031/anies-bangunan-di-pulaureklamasi-legal

Sari, N. (2019, July 2). Anies: Pembongkaran Pulau Reklamasi Akan Sebabkan Kerusakan Lingkungan Luar Biasa Komentar: 1 Home News Megapolitan Anies: Pembongkaran Pulau Reklamasi Akan Sebabkan Kerusakan Lingkungan Luar Biasa. Retrieved from https://megapolitan.kompas.com/rea d/2019/07/02/07062481/aniespembongkaran-pulau-reklamasiakan-sebabkan-kerusakan-lingkungan

Sari, N. (2019, July 30). Batalnya SK Pencabutan Izin Reklamasi dan Upaya Anies Melawan. Retrieved from https://megapolitan.kompas.com/rea d/2019/07/30/07075081/batalnyask-pencabutan-izin-reklamasi-danupaya-anies-melawan?page=all
Sari, N. (2019, July 29). SK Dibatalkan, Anies Diwajibkan Proses Perpanjangan Izin Reklamasi Pulau $H$. Retrieved from https://megapolitan.kompas.com/rea d/2019/07/29/17520591/skdibatalkan-anies-diwajibkan-prosesperpanjangan-izin-reklamasi-pulau$\mathrm{h}$ ?page $=$ all

Tambun, L. T. (2019, June 17). PKS Nilai Anies Telah Penuhi Janji Kampanye Soal Reklamasi. Retrieved from https://www.beritasatu.com/megapo litan/559729/pks-nilai-anies-telahpenuhi-janji-kampanye-soalreklamasi

Tim Detikcom. (2019, June 25). Beda Ahok vs Anies Soal Reklamasi. Retrieved from https://news.detik.com/berita/d4600085/beda-ahok-vs-anies-soalreklamasi

Wahyuni, S. (2015). Qualitative Research Method: Theory and Practice Second Edition. Jakarta: Salemba Empat. 